\title{
ABri amyloidosis
}

INSERM

\section{Source}

INSERM. (1999). Orphanet: an online rare disease and orphan drug data base. ABri amyloidosis. ORPHA:97345

ABri amyloidosis is a rare, neurodegenerative disease characterized by prog ressive cognitive impairment, spastic tetraparesis, and cerebellar ataxia resulting from amyloid deposits in the brain. Spasticity with increased deep tendon reflexes and tone are early symptoms, muscular rigidity evolves later. Prog ressive mental deterioration usually starts with apathy and impaired memory with progression to complete disorientation. 